\title{
A Novel Technique of Morcellation Using a Pneumovesicum After Holmium Laser Enucleation of the Prostate in Complicated Situations: Our Initial Experience and Tips
}

\author{
Bum Sik Tae, Byung Jo Jeon, Hoon Choi, Jae Young Park, Jae Hyun Bae \\ Department of Urology, Korea University Ansan Hospital, Korea University College of Medicine, Ansan, Korea
}

Purpose: To describe our initial experience with a novel method of adenoma retrieval using a pneumovesicum (PNV) after Holmium laser enucleation of the prostate (HoLEP).

Methods: From January 2016 to April 2018, a total of 93 consecutive patients treated with HoLEP were enrolled in this study. For tissue morcellation, we used the PNV morcellation technique for an initial series of 21 patients and the conventional technique (Lumenis VersaCut) for a consecutive series of 72 patients. We compared efficiency and safety between the novel technique and the traditional technique. Subgroup analysis was performed to assess the effectiveness of the current technique in the large prostate $(>70 \mathrm{~mL})$.

Results: There were significant differences in mean age and prostate volume between the 2 groups. However, there were no significant differences in the baseline characteristics and preoperative parameters in the subgroup analysis of large prostates $(>70 \mathrm{~mL})$. The mean morcellation efficiency was higher $(8.50 \pm 1.94$ minutes vs. $1.76 \pm 0.45$ minutes, $\mathrm{P}<0.05)$ and the time of morcellation $(7.81 \pm 1.25$ minutes vs. $34.04 \pm 11.14$ minutes, $\mathrm{P}<0.05)$ was shorter in the PNV group. Moreover, there were no significant differences between groups in hospitalization period ( $2.62 \pm 1.10$ days vs. $2.90 \pm 1.26$ days, $\mathrm{P}=0.852)$ and any other postoperative events, including recatheterization, reoperation, clot retention, and urethral stricture (P-value range, 0.1940.447). In the PNV group, there were some cases of procedure-related complications, including postoperative extravesical leakage (5th case), clot retention (8th case), and recatheterization (9th case).

Conclusions: This method has a higher tissue retrieval efficacy, with the advantage of excellent visibility compared to conventional morcellation. The current method can be applied when a transurethral morcellator is out of order or cannot be used.

Keywords: Prostatic hyperplasia; Holmium; Morcellation; Pneumovesicum

- Research Ethics: This study was approved by the Institutional Review Board of Korea University Ansan Hospital (approval number: 2018AS0132).

Because we retrospectively performed our investigation, the IRB waived the need for informed consent documents from our patients.

- Conflict of Interest: No potential conflict of interest relevant to this article was reported.

\section{INTRODUCTION}

Since its introduction by Gilling et al. [1], Holmium laser enucleation of the prostate (HoLEP) has emerged as a useful treat- ment option for treating bladder outlet obstruction due to benign prostatic hypelasia. The HoLEP guarantees similar and durable functional results, significantly reduced transfusion rate, shorter catheterization period, and shorter hospital stay

Corresponding author: Jae Hyun Bae (iD https://orcid.org/0000-0001-9862-3545 Department of Urology, Korea University Ansan Hospital, Korea University College of Medicine, 123 Jeokgeum-ro, Danwon-gu, Ansan 15355, Korea E-mail: urobae@korea.ac.kr / Tel: +82-31-412-5190 / Fax: +82-31-412-5194 Submitted: August 9, 2018 / Accepted after revision: October 20, 2018

(7) This is an Open Access article distributed under the terms of the Creative Commons Attribution Non-Commercial License (http://creativecommons.org/licenses/by-nc/4.0/) which permits unrestricted non-commercial use, distribution, and reproduction in any medium, provided the original work is properly cited. 
compared to open simple prostatectomy [2,3]. Transurethral intravesical morcellation of resected prostatic adenoma is currently the standard procedure for tissue retrieval after HoLEP.

However, for many surgeons, intravesical morcellation is a very stressful procedure and serves as a barrier to mastering the HoLEP learning curve. This is because the morcellation can damage the bladder when post enucleation bleeding disturbs the vision and when the bladder is not sufficiently distended. Bladder injuries occurring during the HoLEP have been reported ranging from $1.4 \%$ to as much as $5.7 \%[4,5]$. Regarding the site of occurrence of bladder injury, the adenoma is aspirated when the blades are directed downward towards the urinary bladder, which can cause trigonal injury or injury to the posterior wall [6]. Trigonal or posterior wall injury has a potential detrimental effect on micturition because, the trigone and bladder base have many sensory fibers [7]. A recent report also stated that trigonal injury by a morcellator resulted in a vesico-sigmoidal fistula [8].

A significant amount of research has been conducted to increase the efficacy and safety of morcellation. In particular, in a recent randomized clinical trial comparing the morcellation of Piranha (Richard Wolf, Knittlingen, Germany) and VersaCut (Lumenis Ltd., Yokneam, Israel) by Marawan, Piranha showed a slightly higher morcellation rate [9]. However, because the nephroscope lens in the morcellator is small, it is possible that some cases of poor visual acuity may occur when performing the procedure in a large prostate. Additionally, if the morcellator fails, the operation time may be delayed, or the operation may not be performed completely. Therefore, we devised a novel alternative tissue retrieval method to ensure better visibility in cases where the inevitable use of the morcellator is not possible.

\section{MATERIALS AND METHODS}

\section{Study Design and Study Participants}

After approval from the Institutional Review Board (2018AS0132), patients who underwent HoLEP between January 2016 and April 2018 at the Korea University Ansan Hospital were enrolled in this study. One surgeon (JHB) performed HoLEP with the novel tissue retrieval technique and the traditional urethral morcellation. Patients with a history of genitourinary surgery or radiation, interstitial cystitis, genitourinary malignancy, or neurogenic bladder or who missed the preoperative transrectal ultrasonography (TRUS) evaluation were excluded from the study. Patients' characteristics and their preoperative, intraoperative, and postoperative findings were investigated retrospectively.

The preoperative work-up comprised a medical history, physical examination, and routine laboratory tests. In addition, all the patients were evaluated preoperatively through serum prostate-specific antigen estimation, TRUS evaluation, digital rectal examination, urinalysis, and International Prostate Symptom Score (IPSS) estimation. Uroflowmetry and postvoid residual urine measurement by ultrasound were performed both preoperatively and postoperatively. Perioperatively, the enucleation and the morcellation times were recorded, and the weight of the retrieved tissue was measured.

\section{Procedure}

A detailed enucleation procedure was performed as described by Kim et al. [10]. The enucleation procedure was accomplished using a 60 - to $100-\mathrm{W}$ Holmium laser (Versapulse, Lumenis Ltd.) source configured with a 360- $\mu$ end-fire laser fiber. Additionally, a 26F resectoscope (Karl Storz, El Segundo, CA, USA) with a laser bridge was used. The enucleation required laser settings of 2 to $2.4 \mathrm{~J}$ at 25 to $50 \mathrm{~Hz}$.

Conventional morcellation was performed under direct visualization using either the reciprocating or the oscillating morcellator (VersaCut Morcellator, Lumenis) introduced through a 26F outer sheath and the offset nephroscope (Karl Storz), with the blades facing toward the anterior bladder dome during morcellation. Otherwise, the novel technique of morcellation using pneumovesicum (PNV) is as follows. After the enucle-

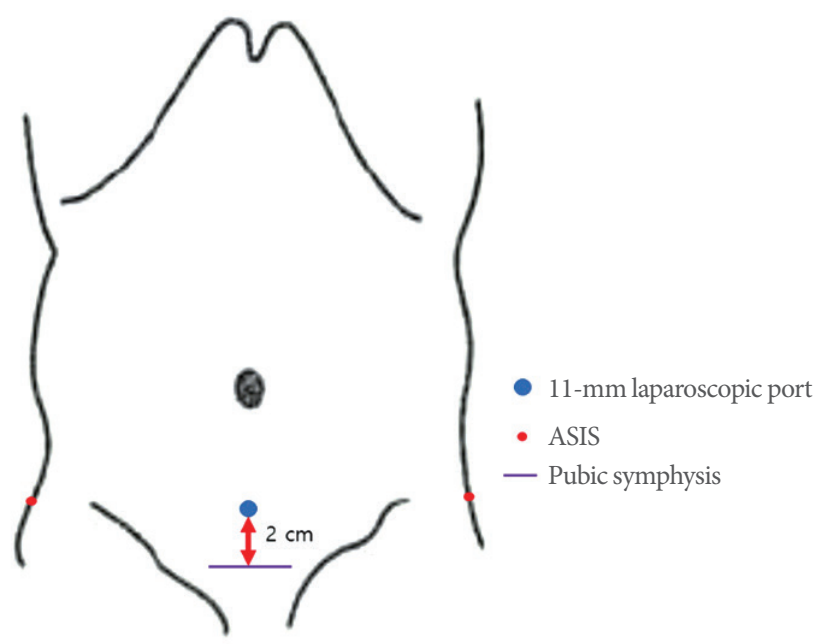

Fig. 1. Port placement procedure. ASIS, anterior superior iliac spine. 
ation of the prostate adenoma, the bladder was filled with normal saline (or $\mathrm{CO}_{2}$ gas) under cystoscopy. An 11-mm laparoscopic self-retaining trocar (Transport, darim SurgNET Ltd., Seoul, Korea) was then inserted $2 \mathrm{~cm}$ away from the pubic symphysis (Fig. 1) under cystoscopic guidance (Fig. 2). After port insertion, the bladder was inflated with $\mathrm{CO}_{2}$ while draining the saline. Insufflation of the bladder occurred via the laparoscopic port with $\mathrm{CO}_{2}$ at a pressure of $10-12 \mathrm{mmHg}$ and flow
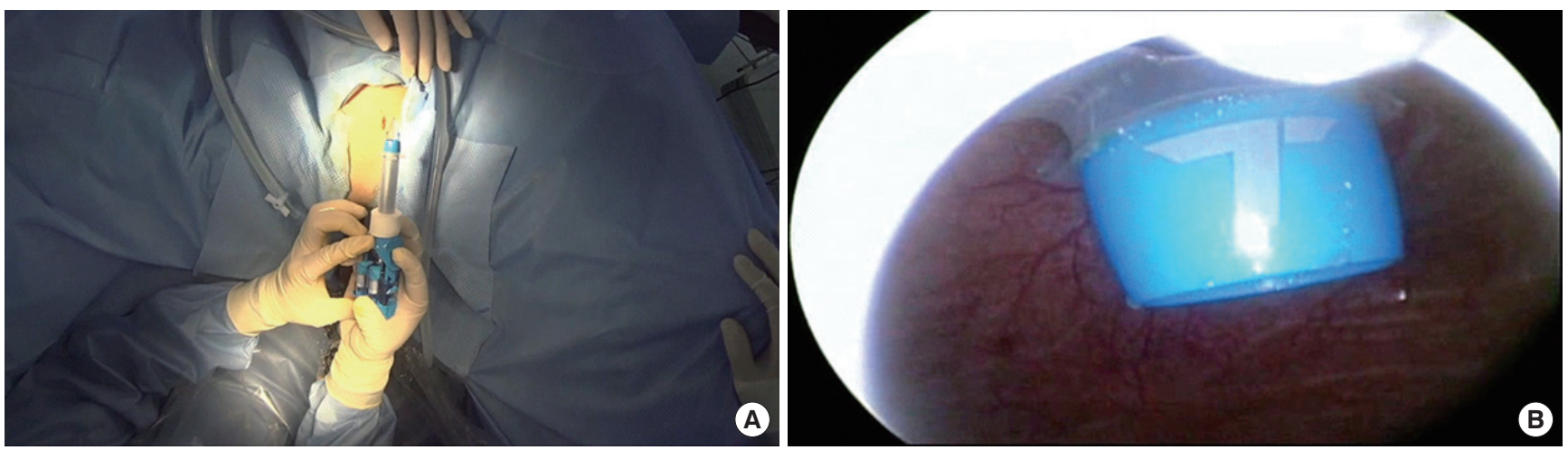

Fig. 2. Port insertion under cystoscopy guidance. (A) An 11-mm laparoscopic self-retaining trocar (Transport, darim SurgNET Ltd., Seoul, Korea) was inserted $2 \mathrm{~cm}$ away from the pubic symphysis under cystoscopic guidance. (B) Establishment of the pneumovesicum while draining the normal saline.
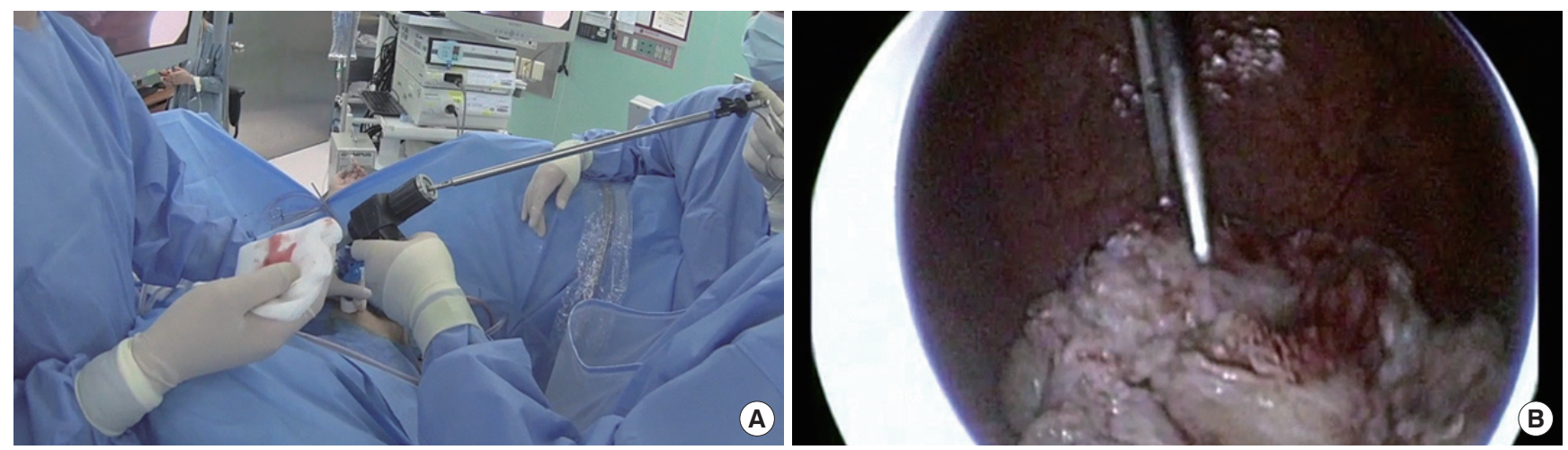

Fig. 3. (A) Holding the resected adenoma with toothed forceps through the laparoscopic morcellator. (B) Holding the resected adenoma with toothed forceps under cystoscopic guidance.
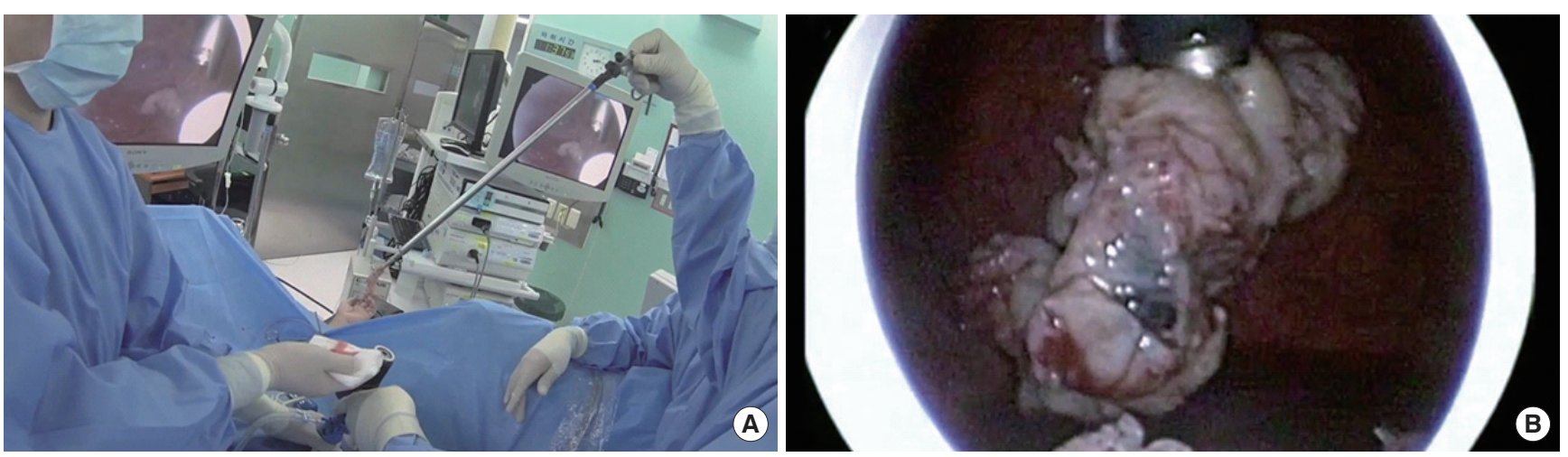

Fig. 4. (A) The morcellation was performed by holding up the resected adenoma. (B) Cystoscopic vision of morcellation with laparoscopic morcellator. 

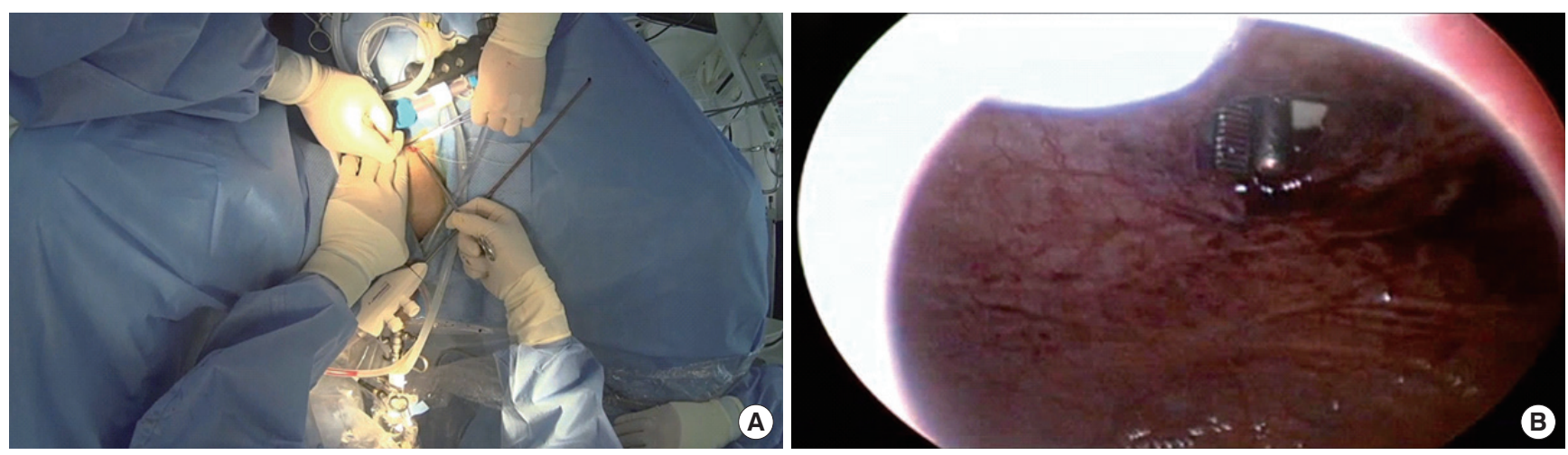

Fig. 5. (A) The bladder mucosa was closed under cystoscopic guidance using a curved absorbable suture or a Carter-Thomason needle whilst maintaining the pneumovesicum. (B) The bladder mucosa was caught with a grasping instrument under cystoscopic guidance close to the bladder.

of 2-3 L/min. After the establishment of the PNV, an 11-mm electromechanical morcellator (Xcise, LiNA Medical, Glostrup, Denmark) which is commonly used in gynecological surgery, was inserted through the port under cystoscopic vision (Fig. 3). Subsequently, a toothed grasping instrument was passed through the central lumen of the device, and the resected adenoma was caught (Fig. 4). The morcellation was performed by holding up the resected adenoma. After the morcellation, the small remnant resected adenomas were removed using the laparoscopic forceps. After removing all the adenomas, the bladder mucosa was closed under cystoscopic vision using a curved absorbable suture or a Carter-Thomason needle while maintaining the PNV (Fig. 5). At the end of the procedure, a 22F 3-way urethral Foley catheter was placed in situ for continuous postoperative irrigation. In general, the flow of the irrigation fluid was reduced gradually and was cutoff the next morning; the catheter was removed after confirming cessation of hematuria.

\section{Definitions and Statistical Analysis}

Morcellation time was defined as the total time needed for removal of the enucleated tissue. The time required for canister changes and vacuum reestablishment was not excluded from the morcellation time for the conventional urethral morcellator, nor was the time required to troubleshoot either device [11]. In the PNV group, morcellation time was calculated from the time of port insertion to wound closure. The enucleation and morcellation efficacies were calculated as the enucleated prostate tissue weight per enucleation time and morcellated tissue weight per morcellation time, respectively.

Subgroup analysis was performed to compare differences in perioperative outcome in patients with a large prostate (prostate volume $>70 \mathrm{~mL}$ ). Statistical analysis was performed using the Student $\mathrm{t}$-test or the Wilcoxon rank-sum test for continuous variables, and the chi-square test for categorical variables. All data are reported as mean and range, considering $\mathrm{P}<0.05$ as statistically significant. All the statistical analyses were conducted using IBM SPSS Statistics ver. 21.0 (IBM Co., Armonk, NY, USA).

\section{RESULTS}

Twenty-one patients underwent successful laparoscopic PNV morcellation after HoLEP at the aforementioned institution. Table 1 summarizes the comparisons in the baseline characteristics and perioperative parameters between the transurethral morcellation $(n=72)$ and PNV morcellation $(n=21)$ groups. The transurethral morcellation group was significantly older (69.53 years vs. 67.29 years, $\mathrm{P}<0.05)$ and had a higher proportion with a history of hypertension than the PNV group. However, prostate volume was significantly larger in the PNV group (70.48 $\mathrm{mL}$ vs. $106.95 \mathrm{~mL}, \mathrm{P}=0.030$ ). The proportion of patients with a history of $5 a$ reductase inhibitors administration, preoperative bacteriuria, concomitant bladder stones and an acute urinary state were higher in the PNV group. Regarding intraoperative parameters, enucleation efficacy $(0.79 \mathrm{~g} / \mathrm{min}$ vs. $0.89 \mathrm{~g} / \mathrm{min})$ and enucleation time (43.91 minutes vs. 59.19 minutes) were higher in the PNV group; however, there were no significant differences in these parameters between the 2 groups $(P>0.05)$. In addition, there were no significant differences in the hospitalization period and occurrence of perioperative complications. However, 
Table 1. Baseline characteristics of patients and perioperative parameters

\begin{tabular}{|c|c|c|c|}
\hline Characteristic & $\begin{array}{l}\text { Conventional morcellation } \\
\text { group }(n=72)\end{array}$ & $\begin{array}{l}\text { PNV morcellation } \\
\text { group }(\mathrm{n}=21)\end{array}$ & P-value \\
\hline Age (yr) & $69.53 \pm 7.82$ & $67.29 \pm 5.62$ & 0.010 \\
\hline Body mass index $\left(\mathrm{kg} / \mathrm{m}^{2}\right)$ & $24.61 \pm 2.52$ & $23.22 \pm 3.87$ & 0.046 \\
\hline $\begin{array}{l}\text { Medical history } \\
\text { Hypertension } \\
\text { Diabetes mellitus } \\
\text { CVA }\end{array}$ & $\begin{array}{l}60(83.3) \\
18(25.0) \\
14(19.4)\end{array}$ & $\begin{array}{l}6(28.6) \\
7(33.3) \\
2(9.5)\end{array}$ & $\begin{array}{l}0.001 \\
0.310 \\
0.239\end{array}$ \\
\hline $\begin{array}{l}\text { IPSS } \\
\text { Total } \\
\text { QoL } \\
\text { Voiding symptom } \\
\text { Storage symptom }\end{array}$ & $\begin{array}{r}25.89 \pm 7.62 \\
4.63 \pm 0.72 \\
14.83 \pm 5.30 \\
11.06 \pm 3.29\end{array}$ & $\begin{array}{r}26.67 \pm 6.97 \\
4.95 \pm 0.67 \\
16.05 \pm 4.07 \\
10.62 \pm 4.01\end{array}$ & $\begin{array}{l}0.767 \\
0.109 \\
0.266 \\
0.228\end{array}$ \\
\hline $\begin{array}{l}\text { Prostate volume }(\mathrm{mL}) \\
\text { Total prostate volume } \\
\text { Transition zone volume } \\
\text { Prostate specific antigen }(\mathrm{ng} / \mathrm{mL})\end{array}$ & $\begin{array}{r}70.48 \pm 37.69 \\
44.78 \pm 25.34 \\
7.78 \pm 12.11\end{array}$ & $\begin{array}{c}106.95 \pm 18.84 \\
60.46 \pm 14.71 \\
5.54 \pm 3.22\end{array}$ & $\begin{array}{l}0.030 \\
0.037 \\
0.090\end{array}$ \\
\hline $\begin{array}{l}\text { Uroflowmetry parameters } \\
\text { Qmax }(\mathrm{mL} / \mathrm{sec}) \\
\text { PVR }(\mathrm{mL}) \\
\text { Concomitant bladder stone } \\
\text { Preoperative bacteriuria } \\
\text { Acute urinary retention }\end{array}$ & $\begin{array}{c}7.38 \pm 4.45 \\
101.94 \pm 133.49 \\
10(13.9) \\
10(13.9) \\
12(16.7)\end{array}$ & $\begin{aligned} 6.09 & \pm 5.85 \\
184.76 & \pm 216.79 \\
7 & (33.3) \\
10 & (47.6) \\
10 & (47.6)\end{aligned}$ & $\begin{array}{l}0.170 \\
0.001 \\
0.049 \\
0.002 \\
0.006\end{array}$ \\
\hline $\begin{array}{l}\text { BPH medication state } \\
\text { Alpha-blocker } \\
\text { 5a-RI }\end{array}$ & $\begin{array}{l}68(94.4) \\
24(33.3)\end{array}$ & $\begin{array}{l}21(100) \\
14(66.7)\end{array}$ & $\begin{array}{l}0.352 \\
0.007\end{array}$ \\
\hline $\begin{array}{l}\text { Intraoperative parameters } \\
\text { Enucleation time (min) } \\
\text { Morcellation time (min) } \\
\text { Enucleation prostate weight }(\mathrm{g}) \\
\text { Enucleation efficacy }(\mathrm{g} / \mathrm{min}) \\
\text { Morcellation efficacy }(\mathrm{g} / \mathrm{min}) \\
\text { Hospitalization period (day) }\end{array}$ & $\begin{array}{c}49.31 \pm 19.79 \\
24.72 \pm 12.86 \\
38.39 \pm 22.80 \\
0.79 \pm 0.28 \\
1.64 \pm 0.54 \\
2.33 \pm 1.32\end{array}$ & $\begin{array}{c}59.19 \pm 23.54 \\
7.81 \pm 1.25 \\
65.48 \pm 13.98 \\
0.89 \pm 0.22 \\
8.50 \pm 1.94 \\
2.90 \pm 1.26\end{array}$ & $\begin{array}{l}0.704 \\
0.001 \\
0.041 \\
0.146 \\
0.001 \\
0.825\end{array}$ \\
\hline $\begin{array}{l}\text { Postoperative events } \\
\text { Recatheterization } \\
\text { Additional TUC for hemostasis after surgery } \\
\text { Clot retention } \\
\text { Urinary incontinence } \\
\text { Urethral stricture } \\
\text { Bladder injury } \\
\text { Extravesical leakage }\end{array}$ & $\begin{array}{l}4(5.6) \\
3(4.2) \\
4(5.6) \\
2(2.8) \\
1(1.4) \\
2(2.8) \\
-\end{array}$ & $\begin{array}{l}1(4.8) \\
0(0) \\
0(0) \\
1(4.8) \\
2(9.5) \\
- \\
1(3.8)\end{array}$ & $\begin{array}{l}0.685 \\
0.460 \\
0.352 \\
0.540 \\
0.127 \\
- \\
-\end{array}$ \\
\hline
\end{tabular}

Values are presented as mean \pm standard deviation or number (\%).

PNV, pneumovesicum; CVA, cerebrovascular accident; IPSS, International Prostate Symptom Score; QoL, quality of life; Qmax, maximal flow rate; PVR, postvoid residual urine; BPH, benign prostatic hyperplasia; $5 a-\mathrm{RI}, 5$ alpha reductase inhibitor; TUC, transurethral coagulation.

tissue retrieval time (24.72 minutes vs. 7.81 minutes) and tissue retrieval efficacy $(1.64 \mathrm{~g} / \mathrm{min}$ vs. $8.50 \mathrm{~g} / \mathrm{min})$ were significantly different between the 2 groups $(\mathrm{P}<0.05)$.

\section{Subgroup Analysis}

A total of 67 patients with a prostate volume $>70 \mathrm{~mL}$ were included in the subgroup analysis; 46 patients in the transurethral morcellation group and 21 in the PNV group (Table 2). There were no significant differences in the baseline characteristics, 
Table 2. Subgroup analysis (prostate volume $>70 \mathrm{~mL}$ ) of baseline characteristics of patients and perioperative parameters

\begin{tabular}{|c|c|c|c|}
\hline Characteristic & $\begin{array}{l}\text { Conventional morcellation } \\
\text { group }(n=46)\end{array}$ & $\begin{array}{l}\text { PNV morcellation } \\
\text { group }(n=21)\end{array}$ & $\mathrm{P}$-value \\
\hline Age (yr) & $70.31 \pm 7.24$ & $67.29 \pm 5.62$ & 0.067 \\
\hline Body mass index $\left(\mathrm{kg} / \mathrm{m}^{2}\right)$ & $24.81 \pm 2.92$ & $23.22 \pm 3.87$ & 0.347 \\
\hline $\begin{array}{l}\text { Past medical history } \\
\text { Hypertension } \\
\text { Diabetes mellitus } \\
\text { CVA history }\end{array}$ & $\begin{array}{r}38(82.6) \\
12(26.1) \\
6(13.0)\end{array}$ & $\begin{array}{l}6(28.6) \\
7(33.3) \\
2(9.5)\end{array}$ & $\begin{array}{l}0.001 \\
0.569 \\
0.514\end{array}$ \\
\hline $\begin{array}{l}\text { IPSS } \\
\text { Total } \\
\text { QoL } \\
\text { Voiding symptom } \\
\text { Storage symptom }\end{array}$ & $\begin{array}{r}29.53 \pm 7.07 \\
4.77 \pm 0.71 \\
17.00 \pm 4.23 \\
12.54 \pm 3.74\end{array}$ & $\begin{array}{r}26.67 \pm 6.97 \\
4.95 \pm 0.67 \\
16.05 \pm 4.07 \\
10.62 \pm 4.01\end{array}$ & $\begin{array}{l}0.744 \\
0.355 \\
0.744 \\
0.270\end{array}$ \\
\hline $\begin{array}{l}\text { Prostate volume }(\mathrm{mL}) \\
\text { Total prostate volume } \\
\text { Transition zone volume } \\
\text { Prostate specific antigen }(\mathrm{ng} / \mathrm{mL})\end{array}$ & $\begin{array}{c}105.88 \pm 42.89 \\
67.56 \pm 18.41 \\
8.99 \pm 7.03\end{array}$ & $\begin{array}{c}106.95 \pm 18.84 \\
60.46 \pm 14.71 \\
5.54 \pm 3.22\end{array}$ & $\begin{array}{l}0.061 \\
0.140 \\
0.063\end{array}$ \\
\hline $\begin{array}{l}\text { Uroflowmetry parameters } \\
\text { Qmax }(\mathrm{mL} / \mathrm{sec}) \\
\text { PVR }(\mathrm{mL}) \\
\text { Concomitant bladder stone } \\
\text { Preoperative bacteriuria } \\
\text { Acute urinary retention state }\end{array}$ & $\begin{array}{c}6.71 \pm 4.27 \\
161.54 \pm 164.13 \\
12(26.1) \\
4(8.7) \\
14(30.4)\end{array}$ & $\begin{array}{c}6.09 \pm 5.85 \\
184.76 \pm 216.79 \\
7(33.3) \\
10(47.6) \\
10(47.6)\end{array}$ & $\begin{array}{l}0.229 \\
0.105 \\
0.370 \\
0.010 \\
0.139\end{array}$ \\
\hline $\begin{array}{l}\text { BPH medication state } \\
\text { Alpha-blocker } \\
5 a-\text { RI }\end{array}$ & $\begin{array}{l}44(95.7) \\
16(34.8)\end{array}$ & $\begin{array}{l}21(100) \\
14(66.7)\end{array}$ & $\begin{array}{l}0.468 \\
0.015\end{array}$ \\
\hline $\begin{array}{l}\text { Intraoperative parameters } \\
\text { Enucleation time (min) } \\
\text { Morcellation time (min) } \\
\text { Enucleation prostate weight }(\mathrm{g}) \\
\text { Enucleation efficacy }(\mathrm{g} / \mathrm{min}) \\
\text { Morcellation efficacy (g/min) } \\
\text { Hospitalization period (day) }\end{array}$ & $\begin{array}{c}68.46 \pm 10.08 \\
34.04 \pm 11.14 \\
58.26 \pm 21.15 \\
0.87 \pm 0.32 \\
1.76 \pm 0.45 \\
2.62 \pm 1.10\end{array}$ & $\begin{array}{c}59.19 \pm 23.54 \\
7.81 \pm 1.25 \\
65.48 \pm 13.98 \\
0.89 \pm 0.22 \\
8.50 \pm 1.94 \\
2.90 \pm 1.26\end{array}$ & $\begin{array}{l}0.002 \\
0.001 \\
0.001 \\
0.012 \\
0.001 \\
0.852\end{array}$ \\
\hline $\begin{array}{l}\text { Postoperative events } \\
\text { Recatheterization } \\
\text { Additional TUC for hemostasis after surgery } \\
\text { Clot retention } \\
\text { Urinary incontinence } \\
\text { Urethral stricture } \\
\text { Bladder injury } \\
\text { Extravesical leakage }\end{array}$ & $\begin{array}{l}0(0) \\
2(4.3) \\
2(4.3) \\
0(0) \\
0(0) \\
1(2.2) \\
-\end{array}$ & $\begin{array}{l}1(4.8) \\
0(0) \\
0(0) \\
1(4.8) \\
2(9.5) \\
- \\
1(4.8)\end{array}$ & $\begin{array}{l}0.447 \\
0.460 \\
0.460 \\
0.447 \\
0.194\end{array}$ \\
\hline
\end{tabular}

Values are presented as mean \pm standard deviation or number (\%).

PNV, pneumovesicum; CVA, cerebrovascular accident; IPSS, International Prostate Symptom Score; QoL, quality of life; Qmax, maximal flow rate; PVR, postvoid residual urine; BPH, benign prostatic hyperplasia; $5 \alpha-R I, 5$ alpha reductase inhibitor; TUC, transurethral coagulation.

prostate volume, and preoperative IPSS score between the 2 groups, except for a history of hypertension and preoperative bacteriuria. However, enucleation time (68.46 minutes vs. 59.19 minutes, $\mathrm{P}=0.002)$, enucleation prostate weight (58.26 g vs. $65.48 \mathrm{~g}, \mathrm{P}=0.001)$, enucleation efficacy $(0.87 \mathrm{~g} / \mathrm{min}$ vs. $0.89 \mathrm{~g} /$ min, $\mathrm{P}=0.012$ ), tissue retrieval time (34.04 minutes vs. 7.81 minutes, $\mathrm{P}=0.001)$, and tissue retrieval efficacy $(1.76 \mathrm{~g} / \mathrm{min}$ vs. $8.50 \mathrm{~g} / \mathrm{min}, \mathrm{P}=0.001$ ) showed significant between-group differences. Postoperative complications and hospitalization periods were similar $(\mathrm{P}>0.05)$. 
Table 3. Subgroup analysis (prostate volume $>70 \mathrm{~mL}$ ) of outcomes of IPSS and uroflowmetry parameters

\begin{tabular}{|c|c|c|c|c|c|c|}
\hline \multirow{2}{*}{ Operation parameter } & \multicolumn{2}{|c|}{$\begin{array}{l}\text { Conventional morcellation } \\
\text { group }(n=46)\end{array}$} & \multirow{2}{*}{ P-value } & \multicolumn{2}{|c|}{$\begin{array}{l}\text { PNV morcellation } \\
\text { group }(n=21)\end{array}$} & \multirow{2}{*}{ P-value } \\
\hline & Preoperative & $\begin{array}{l}\text { Postoperative } \\
\quad(1 \mathrm{mo})\end{array}$ & & Preoperative & $\begin{array}{l}\text { Postoperative } \\
\quad(1 \mathrm{mo})\end{array}$ & \\
\hline Total IPSS & $29.53 \pm 7.07$ & $10.52 \pm 2.40$ & $<0.001$ & $26.67 \pm 6.97$ & $10.50 \pm 2.40$ & $<0.001$ \\
\hline Voiding symptom score & $17.00 \pm 4.23$ & $4.23 \pm 1.75$ & $<0.001$ & $16.05 \pm 4.06$ & $5.24 \pm 1.70$ & $<0.001$ \\
\hline Storage symptom score & $12.54 \pm 3.74$ & $4.23 \pm 1.70$ & $<0.001$ & $10.62 \pm 4.00$ & $5.29 \pm 1.79$ & $<0.001$ \\
\hline QoL & $4.77 \pm 0.71$ & $1.92 \pm 0.48$ & $<0.001$ & $4.95 \pm 0.67$ & $2.71 \pm 0.71$ & $<0.001$ \\
\hline Qmax & $6.71 \pm 4.27$ & $19.79 \pm 6.15$ & $<0.001$ & $6.09 \pm 5.85$ & $19.86 \pm 6.15$ & 0.001 \\
\hline PVR & $161.54 \pm 164.13$ & $20.83 \pm 11.31$ & $<0.001$ & $184.76 \pm 216.78$ & $24.29 \pm 18.86$ & 0.002 \\
\hline
\end{tabular}

Values are presented as mean \pm standard deviation.

IPSS, International Prostate Symptom Score; PNV, pneumovesicum; QoL, quality of life; Qmax, maximal flow rate; PVR, postvoid residual urine.

At 1 month after surgery, both groups demonstrated a significant improvement in total IPSS, all subscores of the IPSS, including storage (IPSS questions $2,4,7$ ), voiding symptoms (IPSS questions $1,3,5,6$ ), and quality of life (Table 3 ). In addition, all uroflow parameters, including maximal flow rate and the post voiding residual volume, improved significantly after surgery in both groups.

Of the 21 patients in the PNV group, 3 manifested a procedure-related complication. An extravesical leakage occurred in the 5th case during the PNV morcellation (Table 1). In this case, an abdominal distension was found due to irrigation fluid after the surgery. The extravesical leakage was seen in the cystography; the urethral catheter was maintained for 7 days. An additional cystography was performed before the removal of the urethral catheter to confirm that there was no extravesical leakage. Meanwhile, the 8th case developed a clot retention after removal of the urethral catheter, and the 9th case manifested failure of the self-voiding capacity after the removal of the urethral catheter on the 2 nd postoperative day; hence, we inserted the catheter again and removed it on the 4th postoperative day.

\section{DISCUSSION}

The HoLEP has been proposed to treat large adenomas with similar efficacy and lower morbidity as compared to open prostatectomy [2,3]. However, the HoLEP has been reported in several studies as a technique for barriers to entry, it has not yet been implemented by the beginners. In addition, Peyronnet et al. [12] recently demonstrated that the learning curves for green laser enucleation of the prostate (GreenLEP) ranged from 14 to
30 cases, and for HoLEP it ranged from 22 to 40 cases. Since the invention of the mechanical tissue morcellator in 1996, various tissue morcellation systems have been tried. However, till date, the VersaCut morcellators have been used most widely [4]. VersaCut morcellators have an average retrieval efficacy of 1.0 to 5.6 $\mathrm{g} / \mathrm{min}$, as reported by most studies; however, there are differences among these studies $[4,10,13]$.

In particular, the morcellation may delay the operation time due to the small visual field of the narrow scope, which may require an additional transurethral resection coagulation due to an unexpected injury. To overcome the limitations of the morcellation, several studies have been published comparing various morcellation methods. Chen et al. [14] have reported a method of reducing the operation time by effectively removing small adenomas that are difficult to catch during the morcellation using alligator forceps. Since fibrotic spherical glands with smooth surfaces and firm tissues can lead to difficulties in catching the pieces of adenomas and suctioning them, they reported a direct tissue removal method using a pair of forceps, which increased the morcellation efficacy up to an average of $7.3 \mathrm{~g} / \mathrm{min}$. In addition, in order to raise the efficacy of morcellation, the Richard Wolf Piranha was introduced with unique features designed to optimize this critical step of the procedure. The Richard Wolf Piranha performs rotating morcellation using serrated blades in which the prostatic tissue moves side to side. Tayeb reported that the Wolf Piranha showed a higher efficiency of $5.6 \mathrm{~g} / \mathrm{min}$ by performing a randomized clinical trial comparing the Wolf Piranha and Lumenis VersaCut [9].

As mentioned above, small adenomas with a firm or smooth surface morphology may delay the surgery time [14]. In addi- 
tion, the presence of dense prostatic tissue (colloquially referred to as "beach balls") can also delay the morcellation time and increase the likelihood of bladder injury due to the morcellation [15]. Patients with frequent retention, frequent catheterization, or recurrent urinary tract infections may develop prostatic tissue inflammation leading to distorted architecture, resulting in an increased gland volume. Monn et al. [15] reported that inflamed prostate tissue may also cause increased bleeding or oozing whilst operating, which may result in poorer visualization requiring increased time to achieve an appropriate hemostasis during surgery.

Patients who underwent the procedure described in this report were those with poor visual acuity. In this case series, $47.6 \%$ of the patients had a history of catheterization, $33.8 \%$ of patients presented with a concomitant bladder stone, and $61.9 \%$ of the patients presented with bacteriuria in the preoperative urine culture. In our institution, the Lumenis VersaCut was used for the morcellation after the enucleation of the prostate. However, in some special situations, the visual field of the transurethral scope was poor or the morcellator was out of order and could not be used. Therefore, we were required to come up with an alternative morcellation method, and we found that this method has some advantages as follows:

First, the PNV allowed an excellent visual field. Even with oozing or bleeding, there was excellent visibility regardless of the prostate volume or amount of bleeding. Second, we could thoroughly remove all small adenoma tissues. Although there are not many reports, it is possible to miss a small floating adenoma tissue after the morcellation; this may require an additional cystoscopic intervention. Third, the current method has an excellent tissue retrieval efficacy, which has shown a greater efficiency than the traditional transurethral morcellation method with an efficiency of up to $5.0 \mathrm{~g} / \mathrm{min}$ using a Lumenis VersaCut or up to $7.0 \mathrm{~g} / \mathrm{min}$ using a Wolf Piranha. Fourth, since morcellation is performed by grabbing the resected adenoma with a grasping instrument passed through the central lumen of the morcellator, it prevents additional bladder injury that may occur during the removal of an adenoma. Since the morcellation is performed by pulling the tissue with a grasping instrument and not by inhalation of air or water, the possibility of bladder collapse or injury is low during the morcellation. Above all, the current method is easy to perform.

Two concepts were used to devise this method. First, procedures using a PNV can be applied to various urologic operations [16]. The PNV should provide excellent vision and should be free from bleeding or oozing in the bladder. Several previous researchers described the advantage of using laparoscopic instruments with the PNV in the removal of complex foreign bodies in the bladder [17-19]. Similar to the previous reports, we regarded resecting the adenoma as foreign body removal and applied this technique. Secondly, a laparoscopic morcellator presents a low risk of unexpected bladder injury during the morcellation. Most unpredictable bladder mucosal injuries occur when the bladder is collapsed. However, the laparoscopic morcellators do not cause bladder collapse without the suction of the $\mathrm{CO}_{2}$ gas. The laparoscopic morcellator is a device that is not familiar to urologists; however, the application of this equipment has recently been reported in some urologic diseases. Asimakopoulos et al. [20] reported on tissue retrieval performed using a laparoscopic morcellator in a case series of huge laparoscopic autosomal-dominant polycystic nephrectomies. However, this study was the first attempt to report tissue removal with a laparoscopic morcellator using a PNV.

This study has some limitations. First, enucleation time, enucleation prostate weight, and enucleation efficacy were shorter in the PNV group. The reason for this is because additional TUC before morcellation is often used in large prostate surgery due to the need for a good visual field to perform conventional morcellation. However, since this method is not affected by operative field oozing, the operation time can be shortened. In addition, when tissue retrieval was performed using this method, resected adenomas were not shredded and could be weighed without tissue loss.

In addition, this method has the limitation that it is not free from complications such as bowel injury or peritoneal leakage as in the case of suprapubic cystostomy insertion. In this series, the patient in the 4th case had urethral catherization for up to 7 days with a peritoneal leakage; however, there were no cases of bowel injury. In this case, a cystography was necessary to confirm that there was no extravasation. In addition, the current tissue retrieval method has a limitation of causing a wound of about $1 \mathrm{~cm}$ in the suprapubic area. Owing to these two critical issues, it is less likely that this method will be applicable to all patients. Nevertheless, this method can be considered as an alternative method that can be useful in situations when a transurethral morcellator is out of order or the morcellation time becomes inevitably extended due to bleeding or poor field of vision. In addition, the current method can be an alternative for an institution where Thulium-LEP or GreenLEP is performed, but it does not possess a transurethral morcellation equipment. 
If a thinner laparoscopic morcellator is developed in the future, a scar-less procedure using a 5-mm port will be possible.

In conclusion, a PNV morcellation using a laparoscopic morcellator is an effective alternative method for the retrieval of resected prostate tissues after HoLEP, as demonstrated in our case series. We introduced tips and tricks for this procedure to aid surgeons who cannot perform a transurethral morcellation after the HoLEP.

\section{AUTHOR CONTRIBUTION STATEMENT}

- Full access to all the data in the study and takes responsibility for the integrity of the data and the accuracy of the data analysis: $B S T, J H B$

- Study concept and design: $B S T, J H B$

- Acquisition of data: BST, HC

- Analysis and interpretation of data: $B S T, J H B$

- Drafting of the manuscript: BST, BJJ

- Critical revision of the manuscript for important intellectual content: BJJ, HC, JYP, JHB

- Statistical analysis: $B S T$

- Administrative, technical, or material support: JHB

- Study supervision: $J H B$

\section{REFERENCES}

1. Gilling PJ, Cass CB, Malcolm AR, Fraundorfer MR. Combination holmium and Nd:YAG laser ablation of the prostate: initial clinical experience. J Endourol 1995;9:151-3.

2. Kuntz RM, Lehrich K, Ahyai SA. Holmium laser enucleation of the prostate versus open prostatectomy for prostates greater than 100 grams: 5-year follow-up results of a randomised clinical trial. Eur Urol 2008;53:160-6.

3. Bae J, Choo M, Park JH, Oh JK, Paick JS, Oh SJ. Holmium laser enucleation of prostate for benign prostatic hyperplasia: Seoul National University Hospital Experience. Int Neurourol J 2011;15:2934.

4. Elshal AM, Mekkawy R, Laymon M, El-Assmy A, El-Nahas AR. Towards optimizing prostate tissue retrieval following holmium laser enucleation of the prostate (HoLEP): assessment of two morcellators and review of literature. Can Urol Assoc J 2015;9:E618-25.

5. Shah HN, Mahajan AP, Hegde SS, Bansal MB. Peri-operative complications of holmium laser enucleation of the prostate: experience in the first 280 patients, and a review of literature. BJU Int 2007;100: 94-101.
6. Lee SH, Choi J, Moon KY, Na W, Lee JB. Holmium laser enucleation of the prostate: modified morcellation technique and results. Korean J Urol 2012;53:779-84.

7. Kuo HC. Bladder base/trigone injection is safe and as effective as bladder body injection of onabotulinumtoxinA for idiopathic detrusor overactivity refractory to antimuscarinics. Neurourol Urodyn 2011;30:1242-8.

8. Kang J, Jung E, Jeon Y, Park I, Lee HG. Laparoscopic repair of a vesicosigmoid fistula secondary to Holmium laser enucleation of the prostate (HoLEP). Urol Case Rep 2017;13:22-3.

9. El Tayeb MM, Borofsky MS, Paonessa JE, Lingeman JE. Wolf Piranha Versus Lumenis VersaCut prostate morcellation devices: a prospective randomized trial. J Urol 2016;195:413-7.

10. Kim M, Lee HE, Oh SJ. Technical aspects of holmium laser enucleation of the prostate for benign prostatic hyperplasia. Korean J Urol 2013;54:570-9.

11. McAdams S, Nunez-Nateras R, Martin CJ, Cha S, Humphreys MR. Morcellation efficiency in Holmium laser enucleation of the prostate: oscillating morcellator outperforms reciprocating morcellator with no apparent learning curve. Urology 2017;106:173-7.

12. Peyronnet B, Robert G, Comat V, Roupret M, Gomez-Sancha F, Cor$\mathrm{nu} \mathrm{JN}$, et al. Learning curves and perioperative outcomes after endoscopic enucleation of the prostate: a comparison between GreenLight 532-nm and holmium lasers. World J Urol 2017;35:973-83.

13. Humphreys MR, Miller NL, Handa SE, Terry C, Munch LC, Lingeman JE. Holmium laser enucleation of the prostate--outcomes independent of prostate size? J Urol 2008;180:2431-5.

14. Chen Q, Chen YB, Wang Z, Peng YB, Zheng DC, Cai ZK, et al. An improved morcellation procedure for holmium laser enucleation of the prostate. J Endourol 2012;26:1625-8.

15. Monn MF, El Tayeb M, Bhojani N, Mellon MJ, Sloan JC, Boris RS, et al. Predictors of enucleation and morcellation time during Holmium laser enucleation of the prostate. Urology 2015;86:338-42.

16. Tae BS, Choi H, Park JY, Bae JH. Laparoscopic approach for intravesical surgery using pneumovesicum in urology: literature review. Int Neurourol J 2018;22(Suppl 1):S10-22.

17. Choi H, Bae JH. Laparoscopic single port cystolithotomy using pneumovesicum. Int Braz J Urol 2016;42:1047-8.

18. Przudzik M, Borowik M, Łesiów R, Purpurowicz Z, Roslan M. Transvesical laparoendoscopic single-site surgery (T-LESS) to remove an unusual foreign body from the bladder. Cent European J Urol 2016;69:312.

19. Ko YH, Kang SG, Kang SH, Park HS, Lee JG, Kim JJ, et al. Removal of long, complex foreign bodies from bladder using single laparoscopic port under pneumovesicum. J Laparoendosc Adv Surg Tech 
A 2010;20:639-42.

20. Asimakopoulos AD, Gaston R, Miano R, Annino F, Mugnier C, Dutto L, et al. Laparoscopic pretransplant nephrectomy with mor- cellation in autosomic-dominant polycystic kidney disease patients with end-stage renal disease. Surg Endosc 2015;29:236-44. 